\title{
Recovery of ammonia and sulfate from waste streams and bioenergy production via
} bipolar bioelectrodialysis

\author{
Zhang, Yifeng; Angelidaki, Irini
}

Published in:

Water Research

Link to article, DOI:

10.1016/j.watres.2015.08.032

Publication date:

2015

Document Version

Peer reviewed version

Link back to DTU Orbit

Citation (APA):

Zhang, Y., \& Angelidaki, I. (2015). Recovery of ammonia and sulfate from waste streams and bioenergy production via bipolar bioelectrodialysis. Water Research, 85, 177-184.

https://doi.org/10.1016/j.watres.2015.08.032

\section{General rights}

Copyright and moral rights for the publications made accessible in the public portal are retained by the authors and/or other copyright owners and it is a condition of accessing publications that users recognise and abide by the legal requirements associated with these rights.

- Users may download and print one copy of any publication from the public portal for the purpose of private study or research.

- You may not further distribute the material or use it for any profit-making activity or commercial gain

- You may freely distribute the URL identifying the publication in the public portal

If you believe that this document breaches copyright please contact us providing details, and we will remove access to the work immediately and investigate your claim 


\section{Accepted Manuscript}

Recovery of ammonia and sulfate from waste streams and bioenergy production via bipolar bioelectrodialysis

Yifeng Zhang, Irini Angelidaki

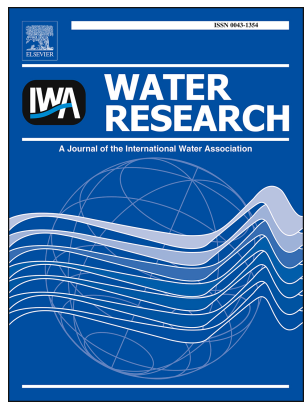

PII: S0043-1354(15)30183-4

DOI: $\quad$ 10.1016/j.watres.2015.08.032

Reference: WR 11479

To appear in: Water Research

Received Date: 29 May 2015

Revised Date: 11 August 2015

Accepted Date: 18 August 2015

Please cite this article as: Zhang, Y., Angelidaki, I., Recovery of ammonia and sulfate from waste streams and bioenergy production via bipolar bioelectrodialysis, Water Research (2015), doi: 10.1016/ j.watres.2015.08.032.

This is a PDF file of an unedited manuscript that has been accepted for publication. As a service to our customers we are providing this early version of the manuscript. The manuscript will undergo copyediting, typesetting, and review of the resulting proof before it is published in its final form. Please note that during the production process errors may be discovered which could affect the content, and all legal disclaimers that apply to the journal pertain. 


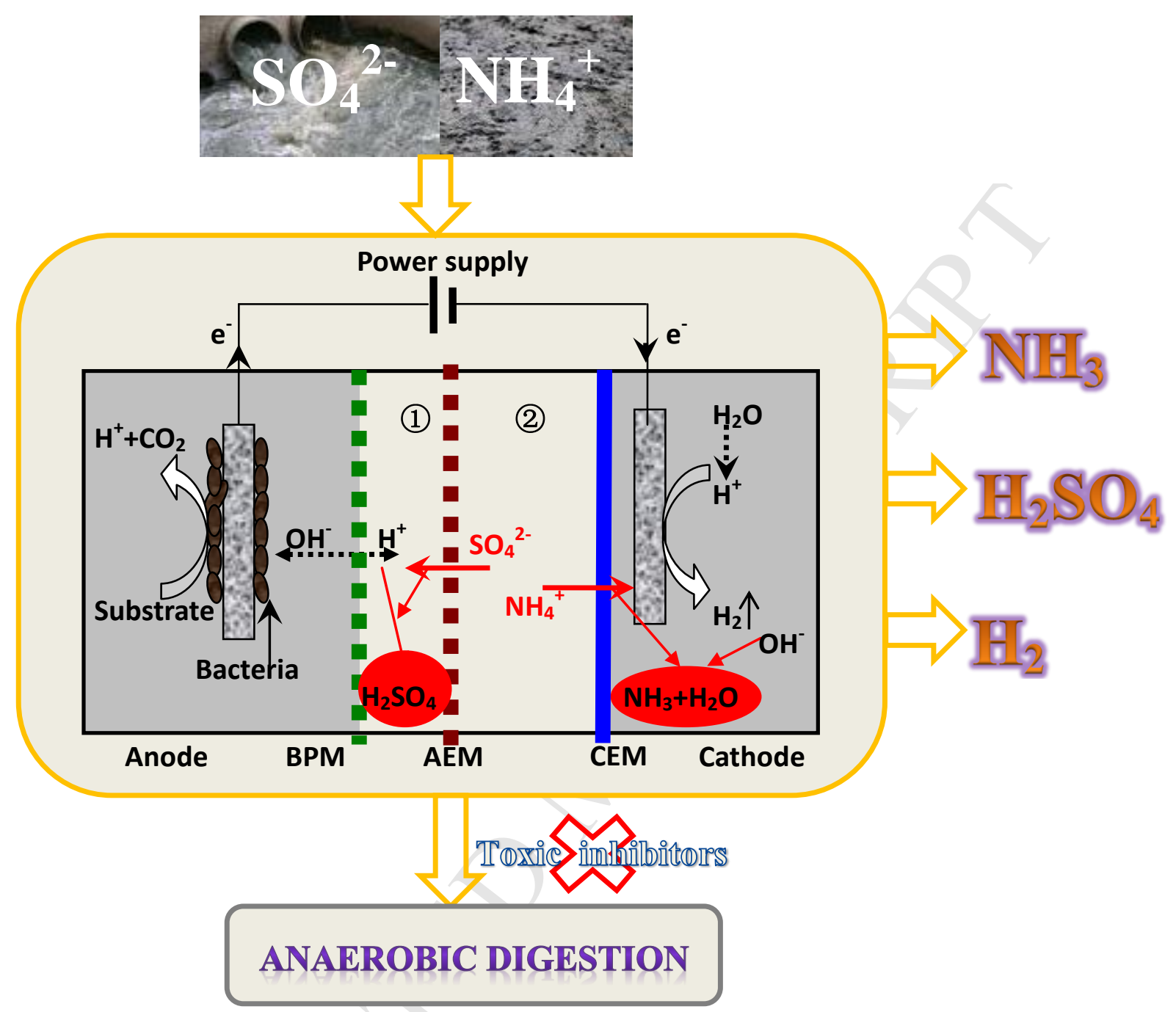


1 Submission to Water Research

2

Date: $19-05-2015$

3

Recovery of ammonia and sulfate from waste

4 streams and bioenergy production via bipolar bioelectrodialysis DK-2800 Lyngby, Denmark 
17

18

19

\section{Abstract}

Ammonia and sulfate, which are prevalent pollutants in agricultural and industrial wastewaters, can cause serious inhibition in several biological treatment processes, such as anaerobic digestion. In this study, a novel bioelectrochemical approach termed bipolar bioelectrodialysis was developed to recover ammonia and sulfate from waste streams and thereby counteracting their toxicity during anaerobic digestion. Furthermore, hydrogen production and wastewater treatment were also accomplished. At an applied voltage of $1.2 \mathrm{~V}$, nitrogen and sulfate fluxes of $5.1 \mathrm{~g} \mathrm{NH}_{4}{ }^{+}-\mathrm{N} / \mathrm{m}^{2} / \mathrm{d}$ and $18.9 \mathrm{~g} \mathrm{SO}_{4}{ }^{2-} / \mathrm{m}^{2} / \mathrm{d}$ were obtained, resulting in a Coulombic and current efficiencies of $23.6 \%$ and $77.4 \%$, respectively. Meanwhile, $\mathrm{H}_{2}$ production of $0.29 \mathrm{~L} / \mathrm{L} / \mathrm{d}$ was achieved. Gas recirculation at the cathode increased the nitrogen and sulfate fluxes by 2.3 times. The applied voltage, initial $\left(\mathrm{NH}_{4}\right)_{2} \mathrm{SO}_{4}$ concentrations and coexistence of other ions were affecting the system performance. The energy balance revealed that net energy $(\geq 16.8 \mathrm{kWh} / \mathrm{kg}-\mathrm{N}$ recovered or $\geq 4.8 \mathrm{kWh} / \mathrm{kg}-\mathrm{H}_{2} \mathrm{SO}_{4}$ recovered) was produced at all the applied voltages $(0.8-1.4$ V). Furthermore, the applicability of bipolar bioelectrodialysis was successfully demonstrated with cattle manure. The results provide new possibilities for development of cost-effective technologies, capable of waste resources recovery and renewable energy production.

Keywords: Bipolar bioelectrodialysis; Bioelectrochemical system; Ammonia; Sulfate; Resources recovery; Waste streams 


\section{Introduction}

Anaerobic digestion is an attractive technology widely used for organic waste treatment and production of energy in the form of biogas (Weiland, 2010). However, the stability of the processes is hard to maintain due to a wide variety of toxic substances, among which free ammonia $\left(\mathrm{NH}_{3}\right)$ and hydrogen sulphide $\left(\mathrm{H}_{2} \mathrm{~S}\right)$ produced from sulfate reduction are two most significant inhibitors (Angelidaki and Ahring, 1994; Siles et al., 2010). Ammonia $\left(\mathrm{NH}_{3} / \mathrm{NH}_{4}{ }^{+}\right)$ and sulfate $\left(\mathrm{SO}_{4}{ }^{2-}\right)$ are often found at high levels $\left(\geq 3 \mathrm{~g} \mathrm{NH}_{4}{ }^{+}-\mathrm{N} / \mathrm{L}\right.$ and up to $13 \mathrm{~g} \mathrm{SO}_{4}{ }^{2-}-\mathrm{S} / \mathrm{L}$, respectively) in the livestock manures and industry residues (Siles et al., 2010). As notorious environmental pollutants, these substances are often found in concentrations much higher than

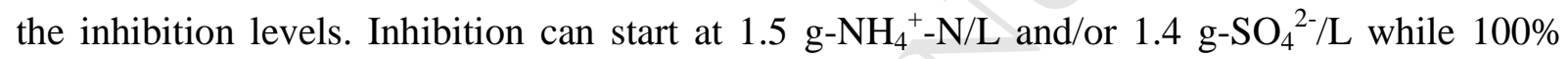

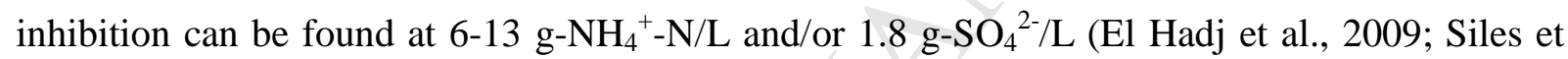
al., 2010). Beside causing inhibition, $\mathrm{H}_{2} \mathrm{~S}$ derived from sulfate reduction can cause serious corrosion in compressors, gas storage tanks and engines, which need to be removed from biogas through energy-extensive processes (Ryckebosch et al., 2011). Several biological, chemical and physical techniques such as bioaugmentation, air stripping and chemical precipitation have been developed to remove or recover excess ammonia and thereby preventing the inhibition (Angelidaki and Ahring, 1994; Angeles De la Rubia et al., 2010; Ippersiel et al., 2012; Westerholm et al., 2012). However, most of the methods are uneconomical, requiring high energy input, have low efficiency, or need of additional chemicals. Most importantly, none of these methods can recover both ammonia and sulfate.

Recently, microbial electrochemical systems (MES) such as Microbial fuel cell (MFC) and microbial electrolysis cell (MEC) have been demonstrated as promising alternatives to conventional air-stripping for ammonia recovery (Kelly and He, 2014; Kuntke et al., 2012; Wu 
and Modin, 2013). Though promising, there are still several challenges need to be addressed before field application. For example, anodic bacteria might be inhibited at high ammonia levels (>4 $\mathrm{g} \mathrm{NH}_{4}{ }^{+}$-N/L) (Kim et al., 2011; Nam et al., 2010). To meet this challenge, microbial desalination cell (MDC) has recently been proposed to recover ammonia from anaerobic reactors (Zhang and Angelidaki, 2014). The principle of MDC has also been successfully applied to upconcentrate nutrients from diluted urine (Tice and Kim, 2014). Nevertheless, the dramatic pH drop in the anode during recovery needs to be prevented before practical application $(\mathrm{Qu}$ et al. 2012). Sulfate is potential electron acceptor in MES (Sun et al., 2009; Zhao et al., 2008), but direct recovery of sulfate (e.g., as sulfuric acid) has never been reported. Therefore, it is of great importance to explore the feasibility of sulfate recovery using MES. Furthermore, an advanced system that can combine ammonia and sulphide recovery should be pursued. An MES namely microbial electrolysis desalination and chemical production cell (MEDCC) was recently developed for water desalination, acid and alkali production (Chen et al., 2012). With an applied voltage $(\sim 1.2 \mathrm{~V}), \mathrm{Cl}^{-}$and $\mathrm{Na}^{+}$in the desalination chamber are driven across an anion exchange membrane (AEM) and a cation exchange membrane (CEM) into acid-production and cathode chambers, where they are recovered as $\mathrm{HCl}$ and $\mathrm{NaOH}$ (Chen et al., 2012). It has been reported that $\mathrm{NH}_{4}{ }^{+}$and $\mathrm{SO}_{4}{ }^{2-}$ have higher ionic conductivity and diffusivity to transport through membranes than that of $\mathrm{Na}^{+}$and $\mathrm{Cl}^{-}$(Tice and Kim, 2014). Thus, $\mathrm{NH}_{4}{ }^{+}$and $\mathrm{SO}_{4}{ }^{2-}$ could be captured in the form of $\mathrm{NH}_{3}$ (from $\mathrm{NH}_{4}{ }^{+}$and $\mathrm{OH}^{-}$) and $\mathrm{H}_{2} \mathrm{SO}_{4}$. In light of the above, the MEDCC could fulfill the requirements for ammonia and sulfate recovery, which has never been reported. Nevertheless, the extensive aeration in the cathode of MEDCC might be one of the key challenges for such new application. 
In this study, we developed a bioelectrochemical system, called in the later as "bipolar bioelectrodialysis", on the basis of MEDCC, for a brand new application with respect to simultaneous ammonia and sulfate recovery from waste streams and hydrogen production. Beside different application scopes, the main advantage of the bipolar bioelectrodialysis over the previous MEDCC is that the energy-intensive aeration at the cathode was replaced with costeffective hydrogen production, which could offset the energy costs during recovery or be stored for further use. The objective of this study was to investigate the feasibility of the bipolar bioelectrodialysis system by varying operational parameters such as applied voltage, initial ammonia and sulfate concentration, and ionic species. Whereas the synthetic wastewater containing varied ammonia and sulfate concentrations was used for the investigation, also cattle manure was used as a proof of concept to demonstrate its applicability. This work demonstrates a new avenue to recover valuable resources from waste streams, produce bioenergy, and potentially prevent inhibitions during anaerobic digestion.

\section{Materials and methods}

\subsection{Experimental setup}

The bipolar bioelectrodialysis system composed of four chambers (inside dimensions $5 \mathrm{~cm} \times 5$ $\mathrm{cm} \times 2 \mathrm{~cm}$ for each, Figure 1) was made of nonconductive polycarbonate. A bipolar membrane (BMP, fumasep® FBM, FuMA-Tech GmbH, Germany), an AEM (AMI 7001, Membrane international, NJ) and a CEM (CMI 7000, Membrane international, NJ) were placed between the anode and cathode chambers. The acid-production chamber was close to the anode side for sulfate recovery. The working chamber was close to the cathode side for receiving waste streams.

The liquid volume of each chamber except anode was $40 \mathrm{~mL}$. There were several openings on each chamber connected with rubber tube for feeding and sampling. The anode electrode was 
made of a carbon fiber brush $(5.0 \mathrm{~cm}$ diameter, $5.0 \mathrm{~cm}$ length, Mill-Rose, USA), which was pretreated at $450{ }^{\circ} \mathrm{C}$ for 30 min prior to use (Al Atraktchi 2014). The pretreated anode was preacclimated with mature biofilm in a MFC operated with wastewater. The cathode was a stainless steel woven mesh $(4.0 \times 4.0 \mathrm{~cm}, 0.24 \mathrm{~mm}$ wire diameter, $1.57 \mathrm{~mm}$ aperture, The Mesh Company, United Kingdom) coated with $0.5 \mathrm{mg} / \mathrm{cm}^{2} \mathrm{Pt}$. All the electrical connection and electrode pretreatment were performed according to previous study (Zhang and Angelidaki, 2012a).

\section{Figure 1 is here}

\subsection{Domestic wastewater, synthetic ammonia and sulfate-rich wastewater and cattle} manure

Domestic wastewater was collected from primary clarifier (Lyngby Wastewater Treatment Plant, Copenhagen, Denmark). The characteristics of the wastewater were as following: chemical oxygen demand (COD) $296 \mathrm{mg} / \mathrm{L}, \mathrm{pH} 7.8$, conductivity $1.4 \mathrm{mS} / \mathrm{cm}$, nitrogen $0.07 \mathrm{~g} \mathrm{NH}_{4}{ }^{+}-\mathrm{N} / \mathrm{L}$, phosphorus $0.01 \mathrm{~g} \mathrm{PO}_{4}{ }^{2-}-\mathrm{P} / \mathrm{L}, \mathrm{Na}^{+} 0.20 \mathrm{~g} / \mathrm{L}, \mathrm{K}^{+} 0.07 \mathrm{~g} / \mathrm{L}, \mathrm{Cl}^{-} 0.19 \mathrm{~g} / \mathrm{L}$, and $\mathrm{SO}_{4}{ }^{2-} 0.04 \mathrm{~g} / \mathrm{L}$. The synthetic wastewater was prepared with deionized water containing $(\mathrm{pH} 6.5)$ : glucose $10 \mathrm{~g} / \mathrm{L}$, $\mathrm{NaCl} 0.10 \mathrm{~g} / \mathrm{L}, \mathrm{MgCl}_{6} \cdot \mathrm{H}_{2} \mathrm{O} 0.10 \mathrm{~g} / \mathrm{L}, \mathrm{CaCl}_{2} 0.05 \mathrm{~g} / \mathrm{L}, \mathrm{NaHCO}_{3} 0.50 \mathrm{~g} / \mathrm{L}$ and trace mineral metals solution $\left(\leq 0.01 \mathrm{~g} / \mathrm{L}\right.$ in total). $\mathrm{NH}_{4}{ }^{+}$and $\mathrm{SO}_{4}{ }^{2-}$ were added at different concentrations according to the tests. The cattle manure was collected from Vegger biogas plant, Denmark. The manure was sieved to remove coarse materials and stored at $4{ }^{\circ} \mathrm{C}$ before use. The characteristics of the manure were: $\mathrm{pH} 8.1$, total solids $79.23 \mathrm{~g} / \mathrm{L}$, volatile solids $60.55 \mathrm{~g} / \mathrm{L}$, total Kjeldahl nitrogen $3.27 \mathrm{~g} / \mathrm{L}, \mathrm{NH}_{4}{ }^{+}-\mathrm{N} 2.15 \mathrm{~g} / \mathrm{L}, \mathrm{SO}_{4}{ }^{2-} 0.03 \mathrm{~g} / \mathrm{L}, \mathrm{Cl}^{-} 8.23 \mathrm{~g} / \mathrm{L}, \mathrm{Ca}^{2+} 0.82 \mathrm{~g} / \mathrm{L}, \mathrm{K}^{+} 3.5 \mathrm{~g} / \mathrm{L}$, $\mathrm{Na}^{+} 0.83 \mathrm{~g} / \mathrm{L}$. The manure was amended with $\mathrm{Na}_{2} \mathrm{SO}_{4}$ to mimic a mixture of ammonia and sulfate-rich waste, obtaining a final $\mathrm{SO}_{4}{ }^{2-}$ concentration of $5 \mathrm{~g} / \mathrm{L}$.

\subsection{Reactor operation}


The domestic wastewater amended with acetate $(2 \mathrm{~g}-\mathrm{COD} / \mathrm{L}$ in total $)$ was recirculated from a feed reservoir (liquid volume of $500 \mathrm{~mL}$ ) through anode at a recirculation rate of $50 \mathrm{~mL} / \mathrm{min}$ using a peristaltic pump (OLE DICH, Instrucmentmakers APS, Denmark). Acetate was used here to eliminate the impact of substrate availability on the system performance. Synthetic wastewater or manure was fed into the working chamber. $\mathrm{NaCl}$ solution $(0.1 \mathrm{M}, \mathrm{pH} 6.9)$ was used as catholyte. Unless stated otherwise, the gas phase of the cathode was internally recirculated at a rate of $50 \mathrm{~mL} / \mathrm{min}$. The feed reservoirs and all the chambers of the system were refilled when the current was lower than $0.2 \mathrm{~mA}$, resulting in a single batch cycle. The reactor and reservoir were purged with nitrogen before starting each batch cycle. External voltage (0.8$1.4 \mathrm{~V}$ ) was supplied by a power supply (HQ PS3003, Helmholt Elektronik A/S, Denmark). The gas stream from cathode passed through adsorption bottle filled with $20 \mathrm{~g} / \mathrm{L}$ boric acid before being collected into foil gas sampling bag. The acid solutions were renewed periodically. Control reactors either operated in open circuit or without gas recirculation were also set up. The external resistance was fixed at $10 \Omega$. All experiments were carried out in duplicate at ambient temperature $\left(22 \pm 3{ }^{\circ} \mathrm{C}\right)$.

\subsection{Electrochemical analysis and calculations}

Kjeldahl nitrogen $(\mathrm{KN}), \mathrm{NH}_{4}{ }^{+}$and $\mathrm{COD}$ were measured according to Standard method (APHA, 1998). $\mathrm{H}_{2}$ was analyzed by a GC-TCD fitted with a $4.5 \mathrm{~m} \times 3 \mathrm{~mm} \mathrm{~s}-\mathrm{m}$ stainless column packed with Molsieve SA (10/80). $\mathrm{Na}^{+}$and $\mathrm{K}^{+}$were measured using Flame atomic absorptions spectrophotometer (FAAS, Shimadzu). $\mathrm{Cl}^{-}$and $\mathrm{SO}_{4}{ }^{2-}$ were quantified by ion chromatography equipped with AS-9-HC column and conductivity detector (Dionex DX-300, Dionex Co., Sunnyvale, CA). pH was measured with a PHM 210 pH meter (Radiometer). Conductivity was determined using a CDM 83 conductivity meter (Radiometer). 
153 Instruments, Inc., Cleveland, OH, USA). Current $(I)$, power $(P=I V)$ and Coulombic efficiency

154 (CE) were calculated as previously described (Zhang and Angelidaki, 2012b). Current density

155 was calculated based on the projected surface area of cathode. The ammonia flux $\left(\mathrm{R}_{\mathrm{N}}\right)$, sulfate 156 flux $\left(\mathrm{R}_{\mathrm{S}}\right)$, cathodic hydrogen recovery $\left(\mathrm{R}_{\mathrm{H} 2}\right)$, current efficiency $(\mathrm{CTE})$ and hydrogen production 157 rate $\left(\mathrm{H}_{2 \mathrm{pr}}\right)$ were calculated as below:

$158 \quad R_{N}=\frac{\Delta\left(m_{N}\right)}{A t}(1)$

$159 \quad R_{S}=\frac{\Delta\left(m_{S}\right)}{A t}$

$160 \quad \mathrm{R}_{\mathrm{H} 2}=\frac{2 F V_{H 2}}{R T \int_{0}^{t} I d t}(3)$

$161 \quad \mathrm{CTE}=\frac{b F \Delta\left(m_{S}\right)}{\int_{0}^{\mathrm{t}} I d t} \times 100 \%$

$162 \quad \mathrm{H}_{2 \mathrm{pr}}=\frac{V_{H 2}}{t V}(5)$

163 Where $\Delta\left(\mathrm{m}_{\mathrm{N}}\right)$ and $\Delta\left(\mathrm{m}_{\mathrm{S}}\right)$ are the transported moles of ammonia and sulfate through membrane; $t$

164 is operation time; $A$ is the projected surface area of AEM or CEM. $V$ is total liquid volume of 165 cathode chamber; $I$ is current; $V H_{2}$ is the measured hydrogen volume; $T$ is the absolute 166 temperature; $R$ is the gas constant; $F$ is Faraday's constant; $b$ is the mole number of electrons 167 transferred per mole of $\mathrm{SO}_{4}{ }^{2-}$.

168 3. Results and discussion

\subsection{The performance of bipolar bioelectrodialysis}


The system performance was studied at batch mode at a voltage of $1.2 \mathrm{~V}$. In the reactor without cathode gas recirculation, the concentration of ammonia in the working chamber decreased from

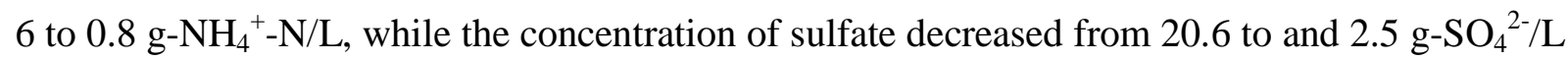
after one batch cycle $(266 \mathrm{~h})$, resulting in a nitrogen and sulfate flux of $5.1 \mathrm{~g}-\mathrm{NH}_{4}{ }^{+}-\mathrm{N} / \mathrm{m}^{2} / \mathrm{d}$ and $18.9{\mathrm{~g}-\mathrm{SO}_{4}}^{2-} / \mathrm{m}^{2} / \mathrm{d}$ (Figure $2 \mathrm{~A}$ ). When gas recirculation was employed at the cathode, the

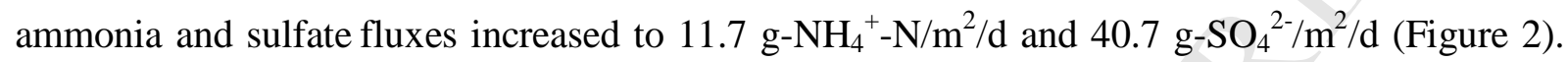
In addition, gas circulation increased the final sulfate concentration in the recovery chamber, while it lowered the final ammonia concentration in the cathode. The enhanced ammonia and sulfate recovery when gas recirculation was applied at the cathode could be due to accelerated mass transfer and improved circuit current (Hou et al., 2014). The gas recirculation at cathode might also have resulted in $\mathrm{NH}_{3}$ stripping from catholyte (discussed later), which could explain the reduced final ammonia concentration in the cathode. In the control reactor under open circuit, ammonia and sulfate concentrations in the working chamber decreased only slightly $(\leq 19 \%)$, indicating the importance of current for driving the transportation of the ions. There were no significant changes in glucose concentration in either condition (data not shown), excluding the diffusion of glucose through membranes. Mass balance for the main ions was established to further elucidate the working mechanism of the bipolar bioelectrodialysis. As shown in Table 1, $85 \%$ of ammonia and $81 \%$ of sulfate were recovered without gas recirculation, while $90 \%$ and $93 \%$ were achieved with gas recirculation. In the reactor without gas recirculation, about $48 \%$ of the recovered ammonia remained at the cathode and another 52\% was finally captured in the acid absorption bottle. However, only $20 \%$ of the recovered ammonia remained at the cathode with gas recirculation and another $80 \%$ was captured in the acid bottle, which supported our earlier assumption that $\mathrm{NH}_{3}$ stripping from the cathode was enhanced with gas recirculation. The 
concentrations of $\mathrm{Na}^{+}$and $\mathrm{Cl}^{-}$in the working chamber increased slightly after one batch cycle (Table 1). It was consistent with control experiment (open circuit), in which slight transportation of $\mathrm{Na}^{+}$and $\mathrm{Cl}^{-}(1.9$ and $2.5 \mathrm{~g} / \mathrm{L}$, data not shown) toward working chamber were detected along with slightly decrease of $\mathrm{NH}_{4}{ }^{+}$and $\mathrm{SO}_{4}{ }^{2-}$, respectively. The results imply that ion exchange might also contribute to the transportation of ammonia and sulfate (Jacobson et al., 2011).

\section{Figure 2 and Table 1 are here}

The $\mathrm{pH}$ in the different chambers is shown in Figure 2B. No significant changes in the anolyte $\mathrm{pH}$ were observed throughout the batch cycle, while the cathode $\mathrm{pH}$ increased from 6.9 to above 9.6 within $24 \mathrm{~h}$ and kept that level until end of operation in both reactors. The $\mathrm{pH}$ in the cathode with gas recirculation (9.99) was slightly higher than that without gas recirculation (9.80). The cathodic $\mathrm{pH}$ is the combination effect of hydrogen evolution and ammonia stripping. The hydrogen evolution could lead to the increase of $\mathrm{pH}$ while ammonia stripping could consume $\mathrm{OH}^{-}$and decrease $\mathrm{pH}$. The gas recirculation could accelerate both processes. According to the result here, it can be deduced that the contribution of gas recirculation to the improvement of hydrogen evolution was more effective than that to the air stripping. Thus, the cathode with gas recirculation showed relatively higher $\mathrm{pH}$. The gas recirculation at cathode also led to significantly lower $\mathrm{pH}$ in the recovery and working chambers ( $\mathrm{pH} 0.9$ and $\mathrm{pH} 1.7$, respectively) compared to that without gas recirculation (1.1 and 3.82, respectively). The drop of $\mathrm{pH}$ in the working chamber was probably due to the diffusion/leakage of $\mathrm{H}^{+}$through AEM (Chen et al., 2012). To avoid the influence of low $\mathrm{pH}$ on the following anaerobic digestion, the effluent from the working chamber could be mixed with some other alkalic substrate or with the effluent from the cathode to adjust the $\mathrm{pH}$. As shown in Figure 2C, the maximum stable current density in the reactor with cathode gas recirculation was approx. $2.7 \mathrm{~A} / \mathrm{m}^{2}$, which was higher than that without 
216 gas recirculation $\left(2.4 \mathrm{~A} / \mathrm{m}^{2}\right)$. In both reactors, current density reached its maximum level at the 217 beginning, and then decreased continuously until the end of batch cycle. This phenomenon was 218 probably attributed to the ions depletion in the working chamber which increased the internal resistance (Cao et al. 2009). The COD consumption (approx. 50\%) in the anode could also partly contribute to the decrease of current density. As expected from the current density, $\mathrm{H}_{2}$ production was also improved with gas recirculation at cathode. $146 \mathrm{~mL}$ of $\mathrm{H}_{2}$ was produced with gas recirculation while only $128 \mathrm{~mL}$ was produced without gas recirculation after a batch circle. The increase in hydrogen production with gas recirculation was consistent with the increase of $\mathrm{pH}$ at the cathode (Figure 2B). In general, the reactor with cathode gas recirculation showed higher $\mathrm{RH}_{2}, \mathrm{CE}$ and CTE compared to that without gas recirculation (Figure 2D). These parameters reached their maximum level at the beginning and then decreased with time in both reactors. For example, $\mathrm{RH}_{2}, \mathrm{CE}$ and CTE reached to $92.7 \%, 36.3 \%$, and $88.7 \%$ in the first $24 \mathrm{~h}$ in the reactor with gas recirculation. Overall, the results in this section demonstrated the feasibility of the bipolar bioelectrodialysis for ammonia and sulfate recovery along with $\mathrm{H}_{2}$ production.

Figure 3 and Table 2 are here

\subsection{The system performance at different applied voltages}

232 Circuit current was the main driving force of ions transportation, thus it is of great importance to elucidate the correlation between different current levels and recovery process by varying the applied voltage. The system performance at different applied voltages is shown in Figure 3. All the parameters including current density, $\mathrm{R}_{\mathrm{N}}, \mathrm{R}_{\mathrm{S}}, \mathrm{H}_{2 \mathrm{pr}}, \mathrm{CE}$, and $\mathrm{RH}_{2}$ increased with the increasing of applied voltage (0.8-1.4 V). For example, current density, $\mathrm{R}_{\mathrm{N}}, \mathrm{R}_{\mathrm{S}}, \mathrm{H}_{2 \mathrm{pr}}, \mathrm{CE}$, and $\mathrm{RH}_{2}$ increased respectively by $76.5 \%, 158 \%, 154 \%, 350 \%, 114 \%$ and $70 \%$ after increasing the voltage from 0.8 
voltage. However, the electric energy consumption would probably increase with voltage and thereby affecting net energy gain. Therefore, energy balance analysis was made (Table 2). The analysis revealed that net energy $\left(\geq 16.8 \mathrm{kWh} / \mathrm{kg}-\mathrm{N}\right.$ or $\left.\geq 4.8 \mathrm{kWh} / \mathrm{kg}-\mathrm{H}_{2} \mathrm{SO}_{4}\right)$ was produced during ammonia and sulfate ions recovery at all the voltages (0.8-1.4 V). The energy gain increased with the voltage till $1.2 \mathrm{~V}$. However, further increasing voltage to $1.4 \mathrm{~V}$ decreased energy production due to increased electric energy consumption in the system. Thus, the optimum voltage for energy recovery in the bipolar bioelectrodialysis system was $1.2 \mathrm{~V}$. The energy produced at $1.2 \mathrm{~V}$ with initial ammonia and sulfate concentration of $6 \mathrm{~g}-\mathrm{N} / \mathrm{L}$ and $20.6 \mathrm{~g}$ $\mathrm{SO}_{4}{ }^{2}$-/L was higher than that obtained with $4 \mathrm{~g}-\mathrm{N} / \mathrm{L}$ and $13.7 \mathrm{~g}-\mathrm{SO}_{4}{ }^{2}-/ \mathrm{L}$. The increased conductivity at relatively higher ammonia and sulfate concentration could be a possible explanation. It was also noticed that the gas recirculation at the cathode didn't reduce the overall energy gain. Instead, more energy was gained due to high $\mathrm{H}_{2}$ production at the cathode. The net energy gained here was higher than that reported in the previous studies concerning MES with ammonia recovery (Kuntke et al., 2012; Wu and Modin, 2013, Zhang and Angelidaki, 2014). Beside the different operation conditions, sulfate recovery could improve energy production. In the light of above, the applied voltage was an important factor affecting the system performance and the system could with advantage be operated at $1.2 \mathrm{~V}$. It should be noted that this preliminary energy analysis didn't include the purification costs for the recovered sulfuric acid, since presence of other ions (i.e., $\mathrm{NaCl}$ in this study) in the recovery chamber could be avoided 258 in continuous operation. In that case, deionized water or low concentration of $\mathrm{H}_{2} \mathrm{SO}_{4}$ instead of $259 \mathrm{NaCl}$ could be just needed at the beginning to initiate the process, but its feasibility needs to be 260 further studied.

\subsection{The effect of initial $\mathrm{NH}_{4}{ }^{+}$and $\mathrm{SO}_{4}{ }^{2-}$ concentrations on system performance}


$262\left(\mathrm{NH}_{4}\right)_{2} \mathrm{SO}_{4}$ was added into the synthetic wastewater at different concentrations to explore the 263 influence of initial ammonia and sulfate concentration on the system performance (Figure 4). 264 Current density increased from 1.7 to $2.7 \mathrm{~A} / \mathrm{m}^{2}$ with the increasing of initial $\left(\mathrm{NH}_{4}\right)_{2} \mathrm{SO}_{4}$

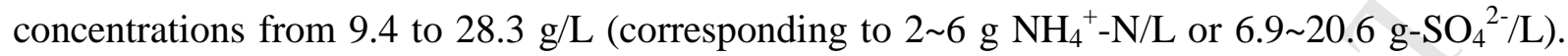

266 The high conductivity contributed by the high $\left(\mathrm{NH}_{4}\right)_{2} \mathrm{SO}_{4}$ concentration might explain the high 267 current density. Along with current density, $\mathrm{R}_{\mathrm{N}}, \mathrm{R}_{\mathrm{S}}, \mathrm{H}_{2 \mathrm{pr}}, \mathrm{CE}$, and $\mathrm{RH}_{2}$ also increased with initial

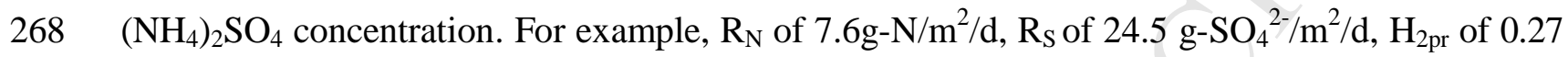
$269 \mathrm{~L} / \mathrm{L} / \mathrm{d}, \mathrm{CE} 19.6 \%$, and $\mathrm{RH}_{2}$ of $56.4 \%$ were obtained at $\left(\mathrm{NH}_{4}\right)_{2} \mathrm{SO}_{4}$ concentration of $9.4 \mathrm{~g} / \mathrm{L}$, while 270 much higher values of $11.7 \mathrm{~g}-\mathrm{N} / \mathrm{m}^{2} / \mathrm{d}, 40.5 \mathrm{~g}-\mathrm{SO}_{4}{ }^{2-} / \mathrm{m}^{2} / \mathrm{d}, 0.54 \mathrm{~L} / \mathrm{L} / \mathrm{d}, 28.9 \%$, and $68.6 \%$ were 271 achieved at $\left(\mathrm{NH}_{4}\right)_{2} \mathrm{SO}_{4}$ concentration of $28.3 \mathrm{~g} / \mathrm{L}$. The results indicate that the bipolar 272 bioelectrodialysis could be applicable to waste streams with wide range of ammonia and sulfate 273 concentrations. The bipolar bioelectrodialysis was targeting the waste streams with high concentration of ammonia and sulfate which can cause severe inhibition during anaerobic digestion, such as livestock manures and industrial wastewaters (or mixture of two by codigestion). Thus, the synthetic wastewater was used to mimic those waste streams. The system could also be applied to the wastewater with low level of ammonia and sulfate (e.g., domestic wastewater), which could be a new application for future study.

\subsection{The effect of other ionic species on $\mathrm{NH}_{4}{ }^{+}$and $\mathrm{SO}_{4}{ }^{2-}$ transportation}

281 Although $\mathrm{SO}_{4}{ }^{2-}$ and $\mathrm{NH}_{4}{ }^{+}$are dominant ions in ammonia and sulfate-rich wastewaters, other ions 282 such as $\mathrm{Cl}^{-}$and $\mathrm{Na}^{+}$might also move through membranes and thereby affecting the recovery 283 processes. Thus, $\mathrm{Cl}^{-}$and $\mathrm{Na}^{+}(150 \mathrm{mM}$ each) were added into the synthetic wastewater 284 containing $300 \mathrm{mM} \mathrm{NH}_{4}{ }^{+}$and $150 \mathrm{mM} \mathrm{SO}_{4}{ }^{2-}$ to investigate their impact on the system 
performance (Figure 5). In the working chamber, $\mathrm{NH}_{4}{ }^{+}$concentration decreased sharply from 300 to $19 \mathrm{mM}$ within $120 \mathrm{~h}$, while $\mathrm{Na}^{+}$concentration decreased slightly from 150 to $124 \mathrm{mM}$ during the same period. Thereafter, $\mathrm{Na}^{+}$concentration decreased dramatically and at the end of batch cycle approached a level lower than $24 \mathrm{mM}$. Similarly, $\mathrm{SO}_{4}{ }^{2-}$ concentration in the working chamber decreased fast in the first $72 \mathrm{~h}(150$ to $57 \mathrm{mM})$, while $\mathrm{Cl}^{-}$concentration was around 125 $\mathrm{mM}$ during this period. Nevertheless, $\mathrm{Cl}^{-}$concentration decreased continuously along with $\mathrm{SO}_{4}{ }^{2-}$ from $72 \mathrm{~h}$ till the end of the batch cycle. Correspondingly, $\mathrm{NH}_{4}{ }^{+}$transportation to the cathode was faster than that of $\mathrm{Na}^{+}$, while $\mathrm{SO}_{4}{ }^{2-}$ transportation to the recovery chamber was faster than that of $\mathrm{Cl}^{-}$(Figure 5B). The initial lag period of the $\mathrm{Na}^{+}$and $\mathrm{Cl}^{-}$transportation could be due to the lack of concentration gradient between the membrane. It has been reported that same level of ionic concentration between membranes can prevent ions diffusion (Desloover et al., 2012). The higher equivalent ionic conductivity of $\mathrm{NH}_{4}{ }^{+}$and $\mathrm{SO}_{4}{ }^{2-}$ over other ions (e.g., $\mathrm{Na}^{+}$and $\mathrm{Cl}^{-}$) could also be responsible for the selective $\mathrm{NH}_{4}{ }^{+}$and $\mathrm{SO}_{4}{ }^{2-}$ transportation (Tice and Kim, 2014). Unlike $\mathrm{Na}^{+}$, ammonia was continuously leaving from the reactor (cathode) in terms of volatile $\mathrm{NH}_{3}$, which might be favorable for selective $\mathrm{NH}_{4}{ }^{+}$transportation. This could also explain the relatively longer lag phase of $\mathrm{Na}^{+}$transportation. It should be noted that current density, $\mathrm{H}_{2}, \mathrm{CE}$ and $\mathrm{R}_{\mathrm{H} 2}$ observed here (Figure S1, Supplementary data) was much higher than that without $\mathrm{NaCl}$ addition in the working chamber shown in Figure 3 (at $1.2 \mathrm{~V}$ ). This was probably due to the increased conductivity after adding $\mathrm{NaCl}$. Thus, the coexistence of other ions didn't affect the ammonia

304 recovery, but it may influence the purity of $\mathrm{H}_{2} \mathrm{SO}_{4}$ recovered at the recovery chamber (e.g., in 305 terms of $\mathrm{HCl}$ ). The acids mixture could be used directly in industries or further purified. It could 306 be interesting to investigate the effect of other cations such as $\mathrm{Ca}^{2+}$ and $\mathrm{K}^{+}$which could also be 307 found in most of waste streams. However, $\mathrm{Ca}^{2+}$ and $\mathrm{K}^{+}$are quite similar to $\mathrm{Na}^{+}$in terms of 
transportation property through cation exchange membrane. It can be expected that $\mathrm{Ca}^{2+}$ and $\mathrm{K}^{+}$ have similar effect as $\mathrm{Na}^{+}$on the system. Thus, the ammonia transportation would not be adversely affected no matter which cation $\left(\mathrm{Ca}^{2+}, \mathrm{K}^{+}\right.$, or $\left.\mathrm{Na}^{+}\right)$presented. Specialized anion exchange membranes that are selective for $\mathrm{NH}_{4}{ }^{+}$and $\mathrm{SO}_{4}{ }^{2-}$ ions could be developed in future to enhance selective recovery from complex waste streams.

\section{Figure 5 is here}

\section{$314 \quad 3.5$ The system performance with cattle manure}

315 The applicability of the bipolar bioelectrodialysis was further verified with cattle manure. As

316 shown in Figure 6, the concentration of $\mathrm{NH}_{4}{ }^{+}$and $\mathrm{SO}_{4}{ }^{2-}$ in the working chamber decreased 317 continuously until the end of batch cycle, while constant accumulation of $\mathrm{NH}_{4}{ }^{+}$and $\mathrm{SO}_{4}{ }^{2-}$ was 318 observed respectively in the cathode and recovery chamber. Consistent with previous 319 observation, $\mathrm{NH}_{4}{ }^{+}$concentration in the cathode was much lower than the level removed from the 320 working chamber due to free $\mathrm{NH}_{3}$ volatilization. More than $94 \%$ of $\mathrm{NH}_{4}{ }^{+}$and $\mathrm{SO}_{4}{ }^{2-}$ in the cattle manure were finally recovered at the end of batch cycle. Current density reached maximum level (approx. $2.3 \mathrm{~A} / \mathrm{m}^{2}$ ) at the beginning and thereafter decreased to $0.8 \mathrm{~A} / \mathrm{m}^{2}$ after $182 \mathrm{~h}$, resulting in an average CE of $27.7 \%$. The remained current density at the end of recovery process could be due to the presence of other ions in the cattle manure which support the conductivity inside of the system. Along with ammonia and sulfate recovery, $\mathrm{H}_{2}$ production at the cathode increased gradually to $150 \mathrm{~mL}$ with an average $\mathrm{R}_{\mathrm{H} 2}$ of $68.2 \%$. The above results demonstrated the applicability of the bipolar bioelectrodialysis to the complex waste streams. The cattle manure amended with $\mathrm{SO}_{4}^{2-}$ was used in this test, further investigation with waste streams originally containing both ammonia and sulfate (e.g., urine) may promote the industrial application of the 
technology. Co-digestion of two waste streams rich either in ammonia or sulfate may also fit well with the application.

\section{Figure 6 is here}

\section{Conclusion}

Ammonia and sulfide derived from sulfate reduction are two notorious toxic compounds in anaerobic digestion processes. Removal or recovery of these inhibitors is always energyintensive and inefficient, and a method that can achieve simultaneous ammonia and sulfate recovery has never been reported so far. It was shown in this study that bipolar bioelectrodilysis was an attractive alternative method to recover ammonia and sulfate and produce hydrogen, allowing the counteraction of their toxicity during anaerobic digestion. The bipolar bioelectrodilysis offers several advantages over conventional methods: (1) This is the first technology which can recover two inhibitors (or its precursor) simultaneously; (2) In-situ recovery without additional chemicals. Instead, hydrogen was produced to make the process selfsustainable; (3) The recovered sulphuric acid could be used to capture ammonia which make the technology even economic feasible; (4) No risk of inhibition on exoelectrogens, as the waste will not be fed into the anode; (5) No need of further $\mathrm{H}_{2} \mathrm{~S}$ removal from the biogas, since its precursor (i.e., sulfate) is recovered, and thereby reducing the biogas upgrading costs; (6) Wastewater treatment can be accomplished through the oxidation in the anode. The extent of recovery could be further optimized by addressing the challenges related to materials (e.g., selective membrane), operation (continuous mode), and microbiology. Especially, the quality of the effluent in each chamber should be considered and optimized. The COD removal in the anode could be further improved by regulating the hydraulic retention time and other operational parameters (e.g., type of wastewater). The catholyte could be reused for several times, which needs to be further 
studied. Furthermore, the $\mathrm{NaCl}$ solution could be replaced by deionized water or $\mathrm{H}_{2} \mathrm{SO}_{4}$ as

354 electrolyte in the recovery chamber in continuous operation to initiate the recovery process and thereby improving the purity of the recovered $\mathrm{H}_{2} \mathrm{SO}_{4}$. Besides, while the ratio of $\mathrm{N} / \mathrm{S}$ was fixed in this study to prove the concept, the influence of different N/S ratios along with individual substance concentrations should be investigated in future to better understand the system. According to the results regarding different initial ammonia and sulfate concentrations, it can be expected that the system could also work at varied ammonia and sulfate ratios. In addition, the bipolar bioelectrodialysis could be linked to anaerobic digestion process for further exploring its effectiveness on biogas enhancement. Considering that large amount of world's biogas plants are suffering economic and energy losses caused by ammonia and sulfide inhibition, there is significant potential for bipolar bioelectrodialysis.

\section{Acknowledgements}

365 The authors thank Hector Garcia for his help with analytical measurements. This study was 366 funded by The Danish Council for Independent Research (DFF-1335-00142).

\section{References}

368 American Public Health Association, A. W. W. A. Water Pollution Control Federation, Standard 369 methods for the examination of water and wastewater, 19th edn. American Public Health 370 Association, Washington, DC. 1998.

371 Alatraktchi, F.A.Z., Zhang, Y., Angelidaki, I., 2014. Nanomodification of the electrodes in 372 microbial fuel cell: impact of nanoparticle density on electricity production and microbial 373 community. Applied Energy 116 (C), 216-222. 
374

375

376

377

378

379

380

381

382

Angeles De la Rubia, M., Walker, M., Heaven, S., Banks, C.J., Borja, R., 2010. Preliminary trials of in situ ammonia stripping from source segregated domestic food waste digestate using biogas: Effect of temperature and flow rate. Bioresource Technology 101(24), 9486-9492. Angelidaki, I., Ahring, B.K., 1994. Anaerobic Thermophilic Digestion of Manure at Different Ammonia Loads - Effect of Temperature. Water Research 28(3), 727-731.

Cao, X., Huang, X., Liang, P., Xiao, K., Zhou, Y., Zhang, X., Logan, B.E., 2009. A new method for water desalination using microbial desalination cells. Environmental Science \& Technology 43(18), 7148-52.

Chen, S., Liu, G., Zhang, R., Qin, B., Luo, Y., 2012. Development of the microbial electrolysis desalination and chemical-production cell for desalination as well as acid and alkali productions. Environmental Science \& Technology 46(4), 2467-72.

Desloover, J., Woldeyohannis, A.A., Verstraete, W., Boon, N., Rabaey, K., 2012. electrochemical resource recovery from digestate to prevent ammonia toxicity during anaerobic digestion. Environmental Science \& Technology 46(21), 12209-12216.

El Hadj, T.B., Astals, S., Gali, A., Mace, S., Mata-Alvarez, J., 2009. Ammonia influence in anaerobic digestion of OFMSW. Water Science and Technology 59(6), 1153-1158.

Hou, Y., Zhang, B., Wen, Z.H., Cui, S.M., Guo, X.R., He, Z., Chen, J.H., 2014. A 3D hybrid of layered $\mathrm{MoS}_{2} /$ nitrogen-doped graphene nanosheet aerogels: an effective catalyst for hydrogen evolution in microbial electrolysis cells. Journal of Materials Chemistry A 2(34), 13795-13800.

Ippersiel, D., Mondor, M., Lamarche, F., Tremblay, F., Dubreuil, J., Masse, L., 2012. Nitrogen potential recovery and concentration of ammonia from swine manure using electrodialysis coupled with air stripping. Journal of Environmental Management 95, S165-S169. 
Jacobson, K.S., Drew, D.M., He, Z., 2011. Use of a liter-scale microbial desalination cell as a platform to study bioelectrochemical desalination with salt solution or artificial seawater. Environmental Science \& Technology 45(10), 4652-7.

Kelly, P.T., He, Z., 2014. Nutrients removal and recovery in bioelectrochemical systems: A review. Bioresource Technology 153, 351-360.

Kim, H.W., Nam, J.Y., Shin, H.S., 2011. Ammonia inhibition and microbial adaptation in continuous single-chamber microbial fuel cells. Journal of Power Sources 196(15), 6210-6213.

Kuntke, P., Smiech, K.M., Bruning, H., Zeeman, G., Saakes, M., Sleutels, T.H.J.A., Hamelers, H.V.M., Buisrnan, C.J.N., 2012. Ammonium recovery and energy production from urine by a microbial fuel cell. Water Research 46(8), 2627-2636.

Nam, J.Y., Kim, H.W., Shin, H.S., 2010. Ammonia inhibition of electricity generation in singlechambered microbial fuel cells. Journal of Power Sources 195(19), 6428-6433.

Qu, Y., Feng, Y., Wang, X., Liu, J., Lv, J., He, W., Logan, B.E., 2012. Simultaneous water desalination and electricity generation in a microbial desalination cell with electrolyte recirculation for $\mathrm{pH}$ control. Bioresource Technology 106, 89-94.

Ryckebosch, E., Drouillon, M., Veruaeren, H., 2011. Techniques for transformation of biogas to biomethane. Biomass \& Bioenergy 35(5), 1633-1645.

Siles, J.A., Brekelmans, J., Martin, M.A., Chica, A.F., Martin, A., 2010. Impact of ammonia and sulphate concentration on thermophilic anaerobic digestion. Bioresource Technology 101(23), 9040-9048.

Sun, M., Mu, Z.X., Chen, Y.P., Sheng, G.P., Liu, X.W., Chen, Y.Z., Zhao, Y., Wang, H.L., Yu, H.Q., Wei, L., Ma, F., 2009. Microbe-assisted sulfide oxidation in the anode of a microbial fuel cell. Environmental Science \& Technology 43(9), 3372-3377. 
419 Tice, R.C., Kim, Y., 2014. Energy efficient reconcentration of diluted human urine using ion

420 exchange membranes in bioelectrochemical systems. Water Research 64, 61-72.

421 Weiland, P., 2010. Biogas production: current state and perspectives. Applied Microbiology and 422 Biotechnology 85(4), 849-860.

423 Westerholm, M., Leven, L., Schnurer, A. 2012. Bioaugmentation of syntrophic acetate-oxidizing 424 culture in biogas reactors exposed to increasing levels of ammonia. Applied and Environmental 425 Microbiology 78(21), 7619-7625.

426 Wu, X., Modin, O., 2013. Ammonium recovery from reject water combined with hydrogen 427 production in a bioelectrochemical reactor. Bioresource Technology 146C, 530-536.

428 Zhang, Y., Angelidaki, I., 2014. Submersible microbial desalination cell for simultaneous 429 ammonia recovery and electricity production from anaerobic reactors containing high levels of 430 ammonia. Bioresource Technology 177, 233-239.

431 Zhang, Y., Angelidaki, I., 2012a. Innovative self-powered submersible microbial electrolysis cell 432 (SMEC) for biohydrogen production from anaerobic reactors. Water research 46(8), 2727-36.

433 Zhang, Y., Angelidaki, I., 2012b. A simple and rapid method for monitoring dissolved oxygen in 434 water with a submersible microbial fuel cell (SBMFC). Biosensors \& Bioelectronics 38(1), 18943594.

436 Zhao, F., Rahunen, N., Varcoe, J.R., Chandra, A., Avignone-Rossa, C., Thumser, A.E., Slade, 437 R.C., 2008. Activated carbon cloth as anode for sulfate removal in a microbial fuel cell. 438 Environmental Science \& Technology 42(13), 4971-6. 
Table 1 Mass balance on the main ions

\begin{tabular}{|c|c|c|c|c|c|c|c|c|c|}
\hline Test & & & $\mathrm{AC}$ & $\mathrm{RC}$ & WC & $\mathrm{CC}$ & $A B^{d}$ & Total & $\begin{array}{l}\text { Balance } \\
(100 \%)\end{array}$ \\
\hline \multirow{8}{*}{$1^{\mathrm{a}}$} & \multirow[b]{2}{*}{$\mathrm{NH}_{4}^{+}(\mathrm{mg})$} & In & $-{ }^{b}$ & 0 & $308.6 \pm 1.1$ & 0 & 0 & $308.6 \pm 1.1$ & \multirow[b]{2}{*}{$98.3 \pm 0.5$} \\
\hline & & out & - & 0 & $41.1 \pm 0.3$ & $128.6 \pm 0.6$ & $133.7 \pm 0.3$ & $303.4 \pm 0.6$ & \\
\hline & \multirow{2}{*}{$\mathrm{SO}_{4}{ }^{2-}(\mathrm{mg})$} & In & - & 0 & $822.9 \pm 0.7$ & 0 & 0 & $822.9 \pm 0.7$ & \multirow{2}{*}{$97.7 \pm 0.3$} \\
\hline & & out & - & $668.0 \pm 0.4$ & $136 \pm 0.7$ & 0 & 0 & $804.0 \pm 1.5$ & \\
\hline & \multirow{2}{*}{$\mathrm{Na}^{+}(\mathrm{mg})$} & In & - & $92.0 \pm 2.9$ & $0.4 \pm 0.1$ & $92.0 \pm 2.9$ & 0 & $184.4 \pm 2.9$ & \multirow{2}{*}{$95.7 \pm 7.5$} \\
\hline & & out & - & $88.0 \pm 5.7$ & $36.4 \pm 5.7$ & $52.0 \pm 11.3$ & 0 & $176.4 \pm 11.3$ & \\
\hline & \multirow{2}{*}{$\mathrm{Cl}^{-}(\mathrm{mg})$} & In & - & $140.0 \pm 8.5$ & $0.2 \pm 0.1$ & $140.0 \pm 8.5$ & 0 & $280.2 \pm 8.5$ & \multirow{2}{*}{$97.8 \pm 4.3$} \\
\hline & & out & - & $116.0 \pm 5.7$ & $20.1 \pm 4.5$ & $138.0 \pm 2.8$ & 0 & 274. & \\
\hline \multirow{8}{*}{ c } & \multirow{2}{*}{$\mathrm{NH}_{4}^{+}(\mathrm{mg})$} & In & - & 0 & $308.6 \pm 1.1$ & 0 & 0 & $308.6 \pm 1.1$ & \multirow{2}{*}{$98.0 \pm 4.1$} \\
\hline & & out & - & 0 & $25.7 \pm 7.3$ & $57.1 \pm 13.8$ & $219.6 \pm 9.1$ & $302.4 \pm 15.6$ & \\
\hline & \multirow{2}{*}{$\mathrm{SO}_{4}{ }^{2-}(\mathrm{mg})$} & In & - & 0 & $822.9 \pm 0.7$ & 0 & 0 & $822.9 \pm 0.7$ & \multirow{2}{*}{$99.6 \pm 4.5$} \\
\hline & & out & - & $764.0 \pm 19.8$ & $56 \pm 16.9$ & 0 & 0 & $820.0 \pm 36.8$ & \\
\hline & \multirow{2}{*}{$\mathrm{Na}^{+}(\mathrm{mg})$} & In & - & $92.0 \pm 2.5$ & $0.4 \pm 0.1$ & $92.0 \pm 2.5$ & 0 & $184.4 \pm 2.9$ & \multirow{2}{*}{$102.2 \pm 3.1$} \\
\hline & & out & - & $96.0 \pm 11.3$ & $28.3 \pm 11.3$ & $64.0 \pm 5.7$ & 0 & $188.3 \pm 5.7$ & \\
\hline & \multirow{2}{*}{$\mathrm{Cl}^{-}(\mathrm{mg})$} & In & - & $140.0 \pm 8.5$ & $0.2 \pm 0.1$ & $140.0 \pm 8.5$ & 0 & $280.2 \pm 8.5$ & \multirow{2}{*}{$98.0 \pm 3.4$} \\
\hline & & out & - & $120 \pm 9.6$ & $16.2 \pm 3.4$ & $138.4 \pm 3.4$ & 0 & $274.6 \pm 9.6$ & \\
\hline
\end{tabular}

\footnotetext{
${ }^{a}$ Without recirculation in the cathode. The data was taken at the end of batch run $(266 \mathrm{~h})$

${ }^{b}$ The ions in the anolyte was not considered, as some of ions might be consumed and their migration to/from the other chambers could be ignored due to BPM separation.

${ }^{c}$ With recirculation in the cathode. The data was taken at the end of batch run $(181 \mathrm{~h})$

${ }^{\mathrm{d}}$ Adsorption bottle filled with boric acid.
} 
ACCEPTED MANUSCRIPT

Table 2 Energy balance analysis based on the batch test

\begin{tabular}{|c|c|c|c|c|c|c|c|}
\hline \multirow[b]{2}{*}{$\begin{array}{c}\text { Voltage } \\
\text { (V) }\end{array}$} & \multirow[b]{2}{*}{$\begin{array}{c}\text { Normalized } \\
\text { Units }\end{array}$} & \multicolumn{2}{|c|}{ Input } & \multicolumn{3}{|c|}{ Output } & \multirow[b]{2}{*}{$\begin{array}{c}\text { Net energy } \\
\text { balance }\end{array}$} \\
\hline & & $\begin{array}{l}\text { Electric } \\
\text { energy }^{\mathrm{a}}\end{array}$ & Pumping $^{\mathrm{b}}$ & $\begin{array}{c}\mathrm{NH}_{3} \\
\text { energy } \\
\text { equiv }^{\mathrm{c}}\end{array}$ & $\begin{array}{l}\mathrm{H}_{2} \mathrm{SO} 4 \\
\text { energy } \\
\text { equiv }^{\mathrm{d}}\end{array}$ & $\mathrm{H}_{2}$ & \\
\hline \multirow{2}{*}{0.8} & $\mathrm{kWh} / \mathrm{kg}-\mathrm{N}$ & $-2.04^{\mathrm{i}}$ & -0.42 & 10.30 & $7.57^{\mathrm{e}}$ & 1.53 & 16.94 \\
\hline & $\mathrm{kWh} / \mathrm{kg}-\mathrm{H}_{2} \mathrm{SO}_{4}$ & -0.59 & -0.12 & $2.96^{\mathrm{e}}$ & 2.18 & 0.44 & 4.87 \\
\hline \multirow{2}{*}{1.0} & $\mathrm{kWh} / \mathrm{kg}-\mathrm{N}$ & -2.54 & -0.27 & 10.30 & $7.58^{\mathrm{e}}$ & 1.92 & 16.99 \\
\hline & $\mathrm{kWh} / \mathrm{kg}-\mathrm{H}_{2} \mathrm{SO}_{4}$ & -0.73 & -0.08 & $2.96^{\mathrm{e}}$ & 2.18 & 0.55 & 4.88 \\
\hline \multirow{2}{*}{1.2} & $\mathrm{kWh} / \mathrm{kg}-\mathrm{N}$ & -2.95 & -0.19 & 10.30 & $7.60^{\mathrm{e}}$ & 2.35 & 17.11 \\
\hline & $\mathrm{kWh} / \mathrm{kg}-\mathrm{H}_{2} \mathrm{SO}_{4}$ & -0.85 & -0.05 & $2.95^{\mathrm{e}}$ & 2.18 & 0.67 & 4.90 \\
\hline \multirow{2}{*}{$1.2^{\mathrm{f}}$} & $\mathrm{kWh} / \mathrm{kg}-\mathrm{N}$ & -2.75 & -0.16 & 10.30 & $7.69^{\mathrm{e}}$ & 2.40 & 17.48 \\
\hline & $\mathrm{kWh} / \mathrm{kg}-\mathrm{H}_{2} \mathrm{SO}_{4}$ & -0.78 & -0.04 & $2.92^{\mathrm{e}}$ & 2.18 & 0.68 & 4.96 \\
\hline \multirow{2}{*}{$1.2^{\mathrm{g}}$} & $\mathrm{kWh} / \mathrm{kg}-\mathrm{N}$ & -2.67 & $-\mathrm{h}$ & 10.30 & $7.58^{\mathrm{e}}$ & 2.11 & 17.32 \\
\hline & $\mathrm{kWh} / \mathrm{kg}-\mathrm{H}_{2} \mathrm{SO}_{4}$ & -0.77 & - & $2.96^{\mathrm{e}}$ & 2.18 & 0.61 & 4.98 \\
\hline \multirow{2}{*}{1.4} & $\mathrm{kWh} / \mathrm{kg}-\mathrm{N}$ & -3.56 & -0.16 & 10.30 & $7.64^{\mathrm{e}}$ & 2.58 & 16.80 \\
\hline & $\mathrm{kWh} / \mathrm{kg}-\mathrm{H}_{2} \mathrm{SO}_{4}$ & -1.02 & -0.04 & $2.94^{\mathrm{e}}$ & 2.18 & 0.74 & 4.80 \\
\hline
\end{tabular}

${ }^{\mathrm{a}}$ Based on the current over the batch cycle

${ }^{\mathrm{b}}$ Estimated according to hydraulic head loss and theoretic equation (in Supplementary data).

${ }^{c}$ Assumed energy consumption for Haber-Bosch process

${ }^{\mathrm{d}}$ Assumed energy consumption for wet sulfuric acid process

${ }^{\text {e }}$ Calculated based on the mole ratio of recovered $\mathrm{NH}_{3}$ and $\mathrm{SO}_{4}{ }^{2}$ in each batch

${ }^{\mathrm{f}}$ The initial $\mathrm{NH}_{4}{ }^{+}-\mathrm{N}$ and $\mathrm{SO}_{4}{ }^{2-}$ concentration in the $\mathrm{WC}$ was 6 and $20.6 \mathrm{~g} / \mathrm{L}$ (mole ratio of 2:1).

${ }^{\mathrm{g}}$ The initial $\mathrm{NH}_{4}{ }^{+}-\mathrm{N}$ and $\mathrm{SO}_{4}{ }^{2-}$ concentration in the $\mathrm{WC}$ was 6 and $20.6 \mathrm{~g} / \mathrm{L}$ (mole ratio of 2:1), but without cathode recirculation.

${ }^{\mathrm{h}}$ not applicable

${ }^{\mathrm{I}}$ Minus means energy cost, while positive means energy gain 


\section{ACCEPTED MANUSCRIPT}

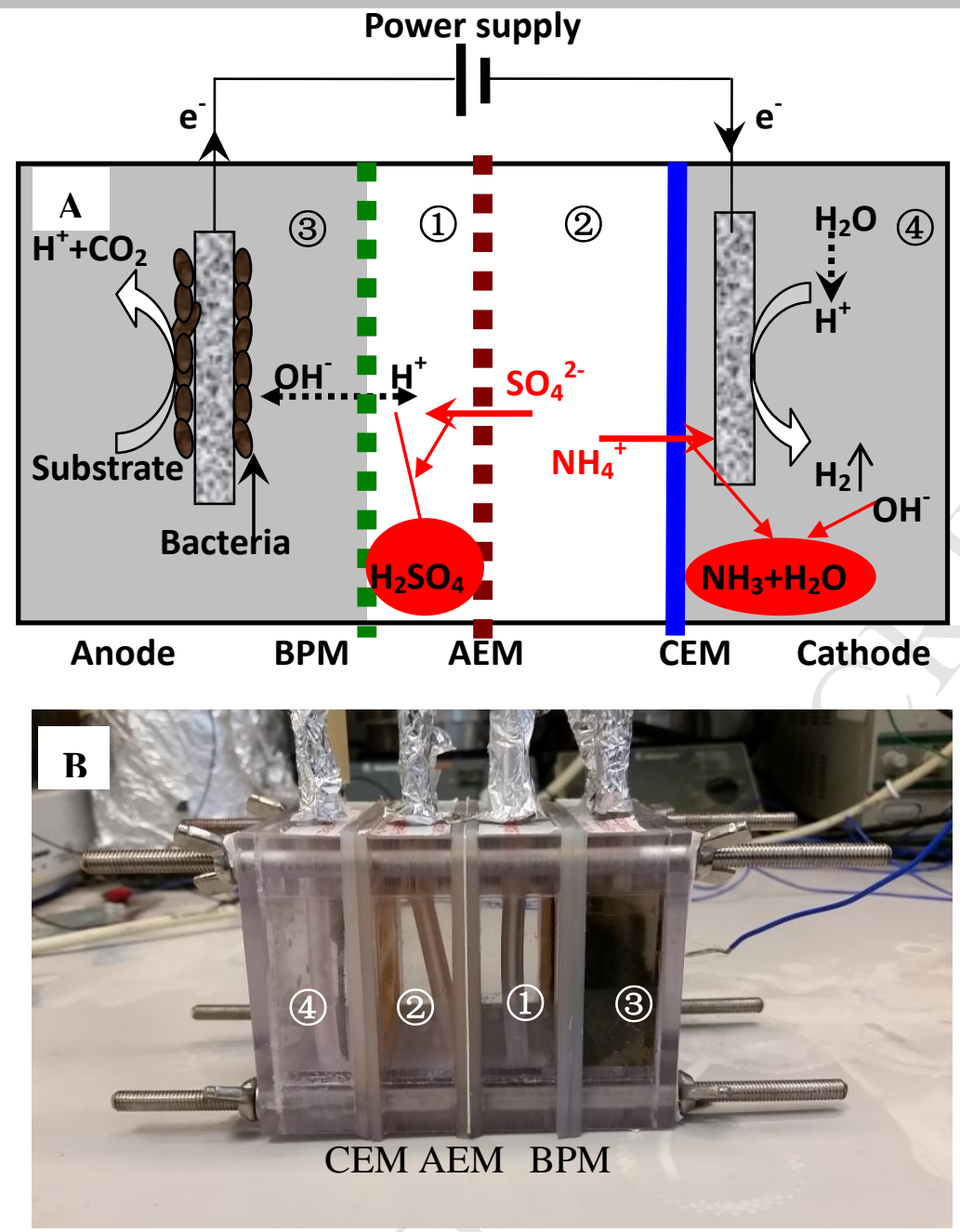

Figure 1 Schematic illustration (A) and image (B) of the bipolar bioelectrodialysis from opposite view. (1) Recovery chamber, (2) Working chamber, (3) Anode, (4) Cathode. 


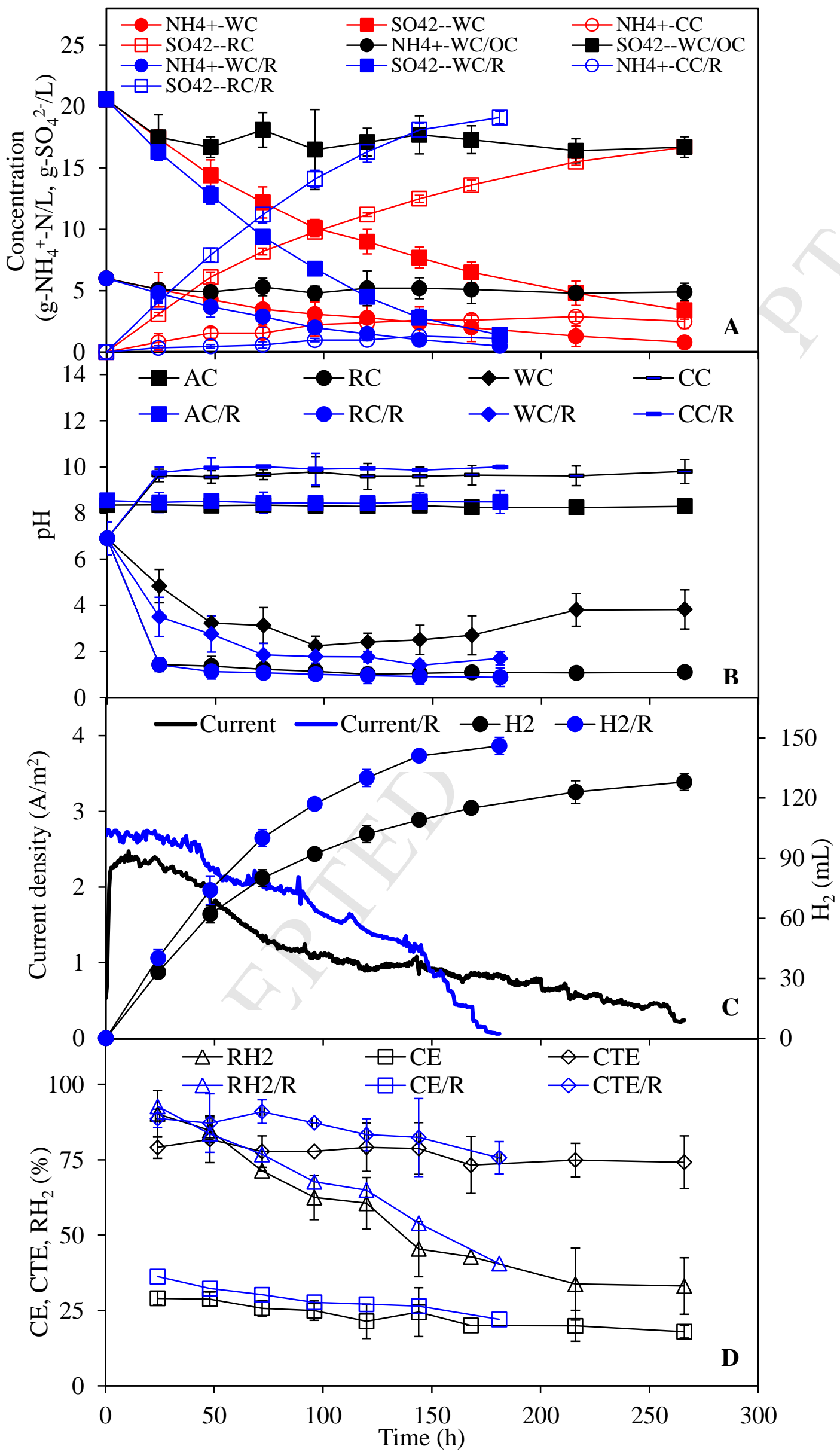




\section{ACCEPTED MANUSCRIPT}

Figure 2 Change of process performances with time. (A) $\mathrm{NH}_{4}{ }^{+}$and $\mathrm{SO}_{4}{ }^{2-}$ concentrations; (B) $\mathrm{pH}$ in different chambers; (C) Current and hydrogen production; (D) CE, CTE and RH2. AC, anode chamber; RC, recovery chamber; WC, working chamber; CC, cathode chamber; OC, open circuit; $\mathrm{R}$, gas recirculation in the cathode. 


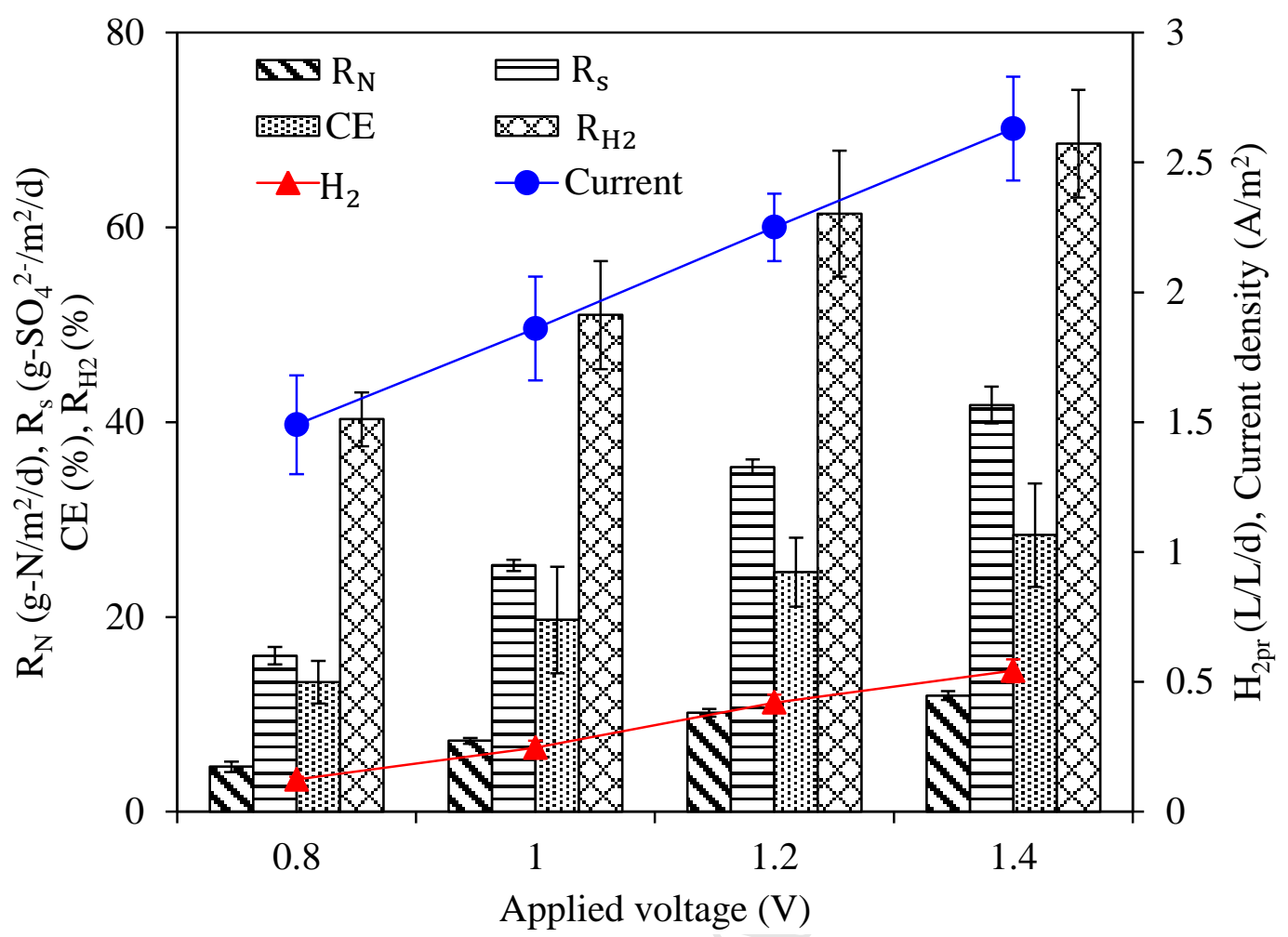

Figure 3 Process performances at different applied yoltages. The initial $\mathrm{NH}_{4}{ }^{+}-\mathrm{N}$ and $\mathrm{SO}_{4}{ }^{2-}$ concentration in the WC was 4 and $13.7 \mathrm{~g} / \mathrm{L}$ (mole ratio of 2:1). 


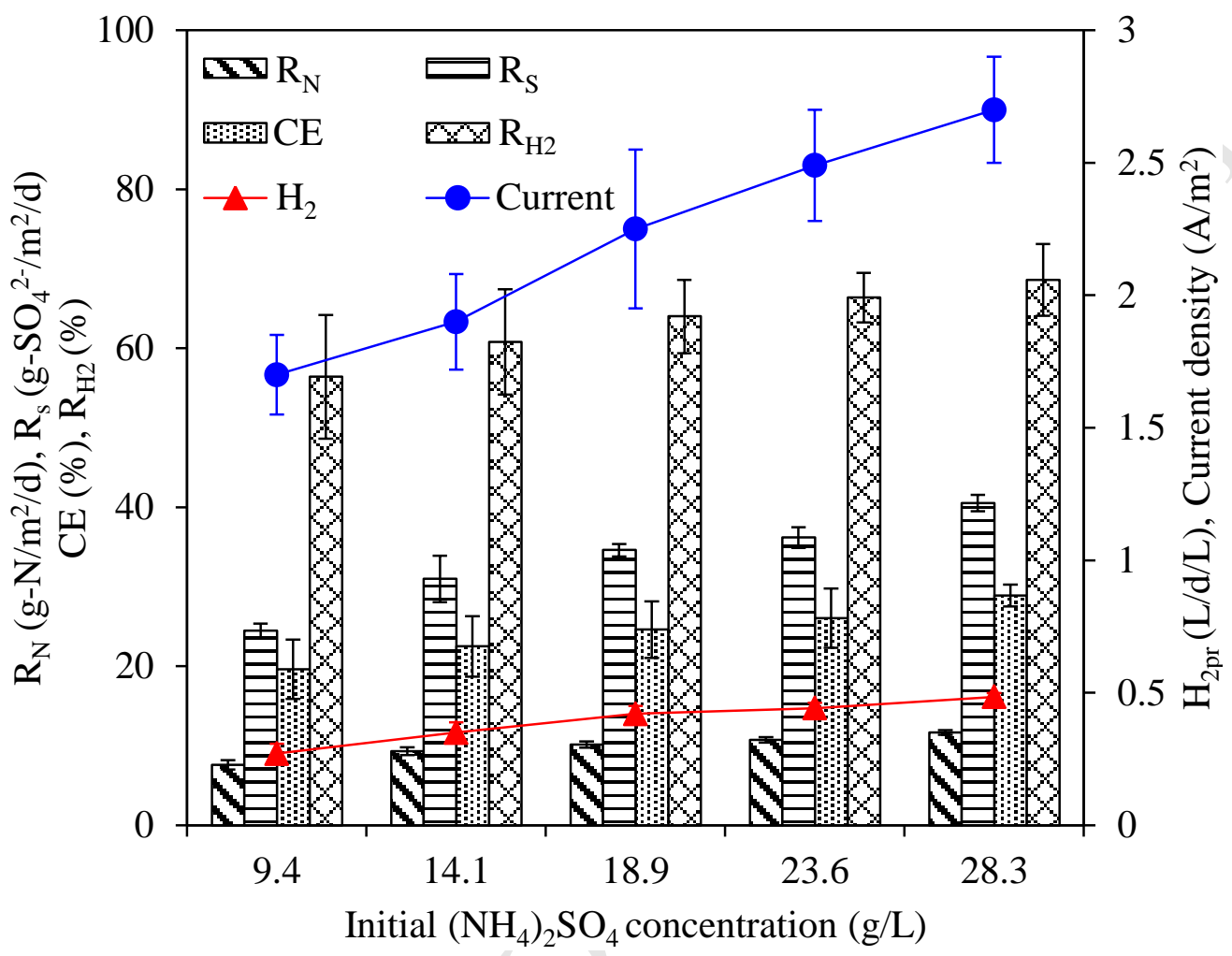

Figure 4 Process performances at different initial $\left(\mathrm{NH}_{4}\right)_{2} \mathrm{SO}_{4}$ concentration. The applied voltage was $1.2 \mathrm{~V}$. 


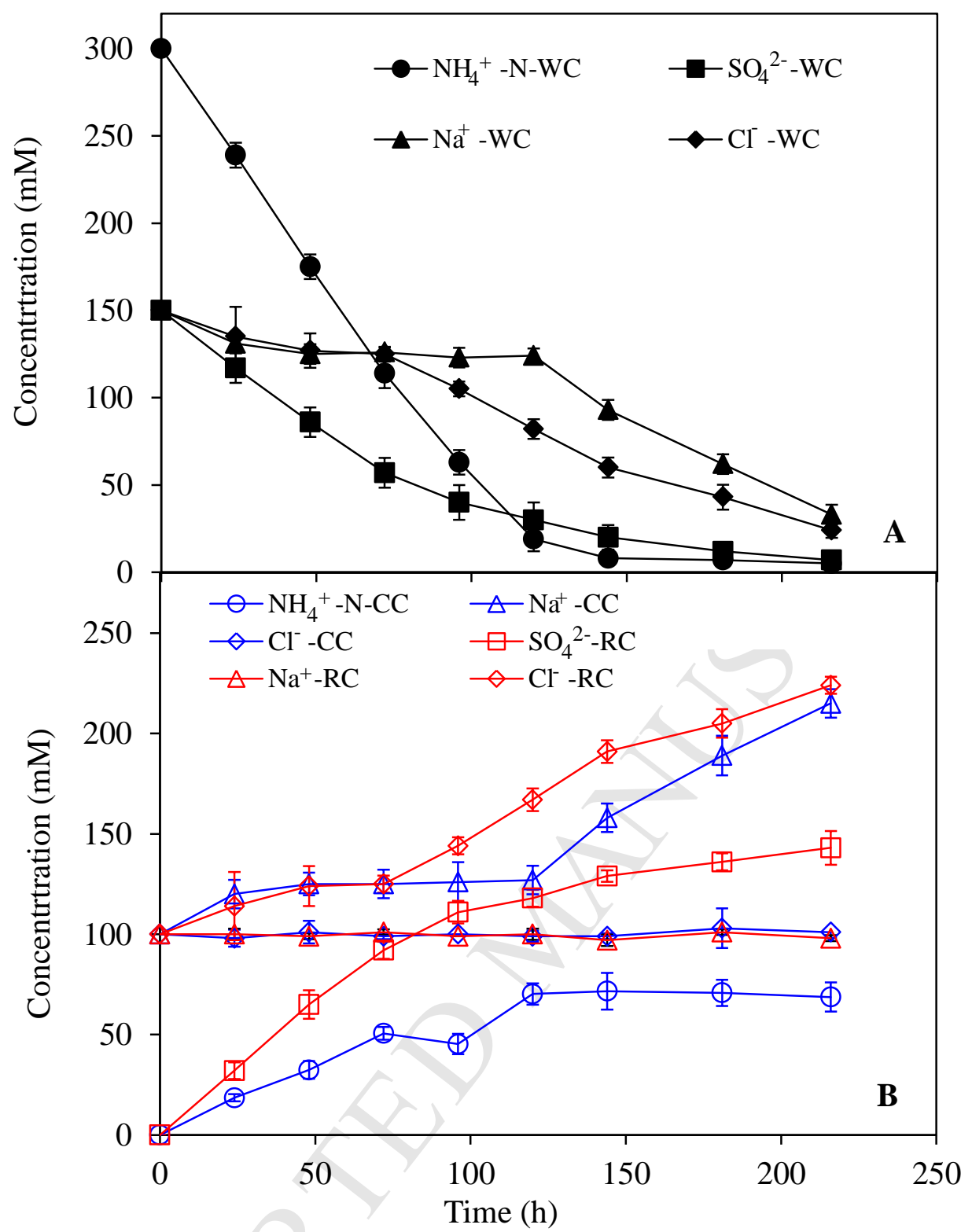

Figure 5 The change of main ions with time in the different chambers. (A) Working chamber; (B) Recovery chamber and cathode chamber. The applied voltage was $1.2 \mathrm{~V}$. The initial concentration of $\mathrm{NH}_{4}{ }^{+}, \mathrm{SO}_{4}{ }^{2-}, \mathrm{Cl}^{-}$and $\mathrm{Na}^{+}$in the synthetic wastewater was $300,150,150$ and $150 \mathrm{M}$, respectively. 


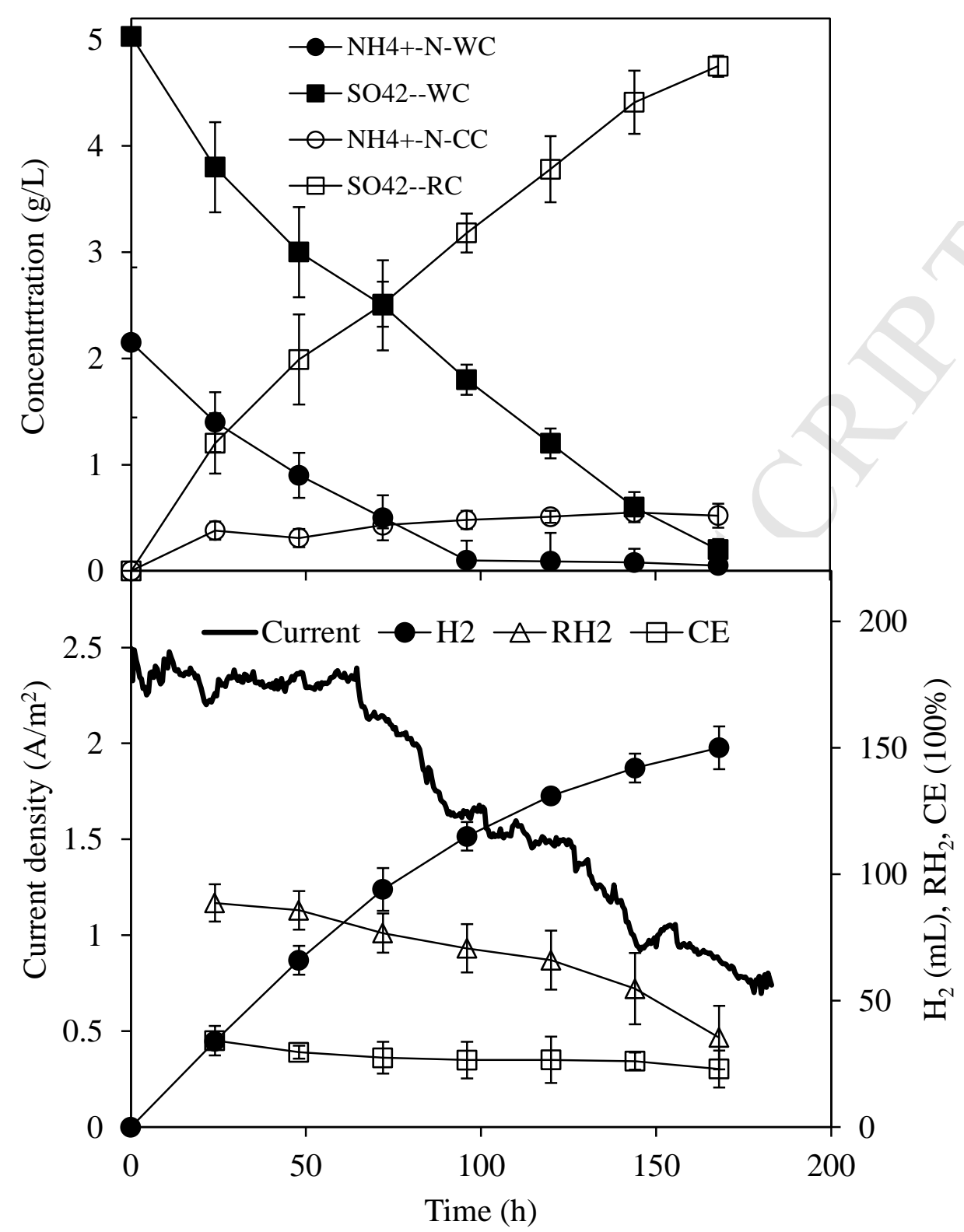

Figure 6 The system performance with cattle manure. The applied voltage was $1.2 \mathrm{~V}$. 
- Novel bipolar bioelectrodialysis for ammonia and sulfate recovery from wastes.

- Hydrogen production and wastewater treatment were accomplished along with recovery.

- Cathodic gas recirculation increased the nitrogen and sulfate fluxes by 2.3 times.

- The system was affected by the voltage, other ions, $\mathrm{NH}_{4}{ }^{+}$and $\mathrm{SO}_{4}{ }^{2-}$ concentrations.

- $\quad$ Net energy was produced at all the applied voltages between 0.8 and $1.4 \mathrm{~V}$. 


\section{Supplementary data}

Page: 3; Figure: 1

Recovery of ammonia and sulfate from waste streams and bioenergy production via bipolar bioelectrodialysis Yifeng Zhang*, Irini Angelidaki

Department of Environmental Engineering, Building 113, Technical University of Denmark, DK-2800 Lyngby, Denmark

*Corresponding author. Tel: (+45) 45251410. Fax: (+45) 45933850. E-mail address:

yifz@env.dtu.dk,yifzmfc@gmail.com. 


\section{Calculations}

Power requirement by the pump was estimated as ${ }^{1}$ :

$P=\frac{Q \gamma E}{1000}$

where $P$ is power requirement $(\mathrm{kW}), \mathrm{Q}$ is flow rate $\left(\mathrm{m}^{3} / \mathrm{s}\right), \gamma$ is $9800 \mathrm{~N} / \mathrm{m}^{3}$, and $\mathrm{E}$ is the hydraulic pressure head (m). For the anolyte recirculation, Q was $8.3 \times 10-7 \mathrm{~m}^{3} / \mathrm{s}$ (50 $\mathrm{mL} / \mathrm{min})$. The measured hydraulic pressure head loss was $0.025 \mathrm{~m}$. Therefore, the power required was $2.03 \times 10^{-7} \mathrm{~kW}$ for the anolyte recirculation pump. The energy required over the batch test ( $94 \mathrm{~h})$ was $1.91 \times 10^{-5} \mathrm{kWh}$.

\section{Reference}

1. Xiao, L.; Young, E. B.; Berges, J. A.; He, Z. Environ. Sci. Technol. 2012, 46, 11459-11466. 


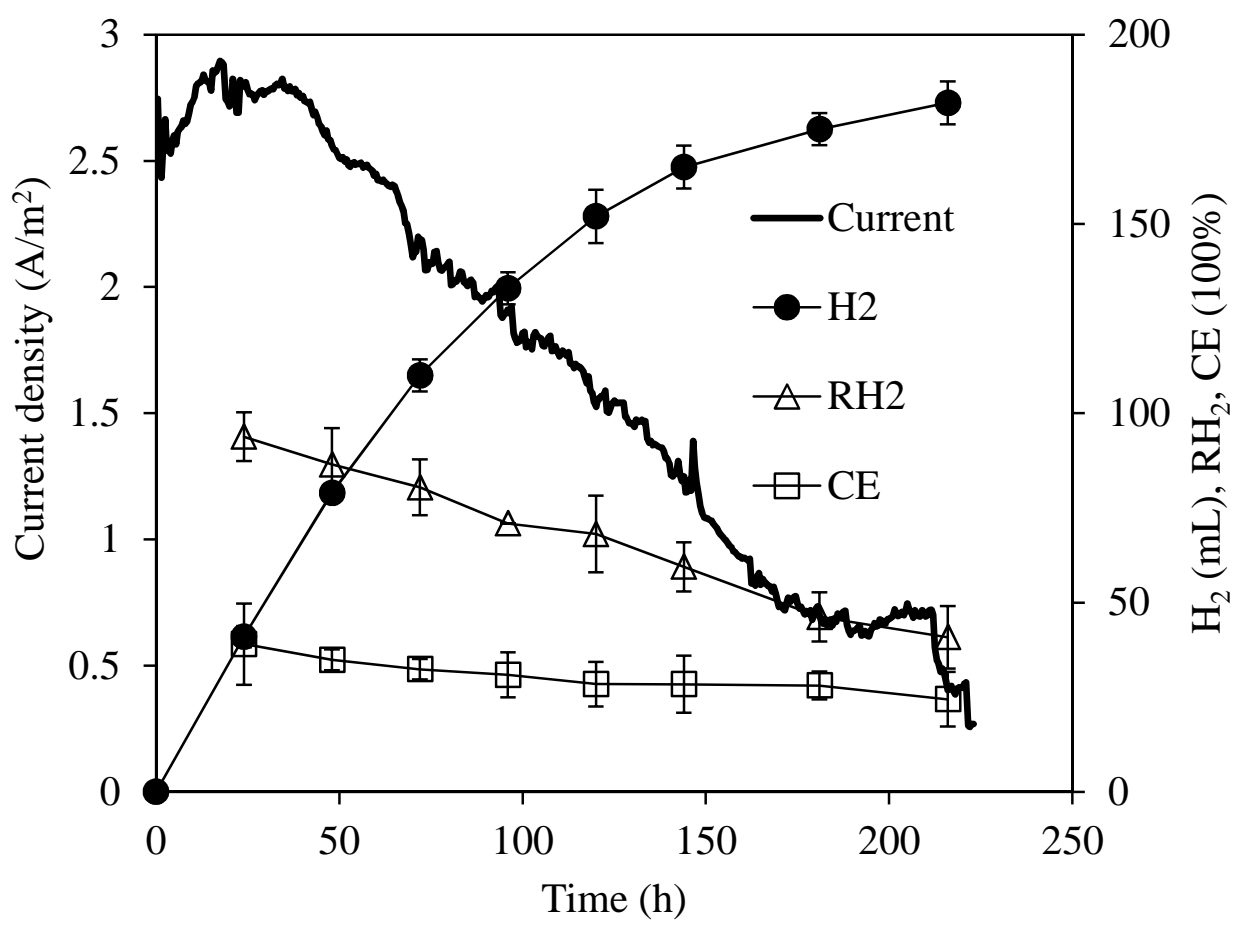

Figure S1 Process performance with the appearance of other ions in the synthetic wastewater. The applied voltage is $1.2 \mathrm{~V}$. The initial concentration of $\mathrm{NH}_{4}{ }^{+}, \mathrm{SO}_{4}{ }^{2-}, \mathrm{Cl}^{-}$ and $\mathrm{Na}^{+}$in the synthetic wastewater was $300,150,150$ and $150 \mathrm{M}$, respectively. 